\title{
Review
}

\section{Revisiting the casing layer: Casing materials and management in Agaricus mushroom cultivation}

\section{Revisitando a camada de cobertura: Materiais e manejo da camada de cobertura no cultivo dos cogumelos Agaricus}

\author{
Eustáquio Souza Dias ${ }^{1 *}(\mathbb{D})$, Diego Cunha Zied ${ }^{2}(\mathbb{D})$ Arturo Pardo-Gimenez $^{3}(\mathbb{D})$
}

\author{
'Universidade Federal de Lavras/UFLA, Departamento de Biologia/DBI, Lavras, MG, Brasil \\ ${ }^{2}$ Universidade Estadual Paulista/UNESP, Faculdade de Ciências Agrárias e Tecnológicas/FCAT, Dracena, SP, Brasil \\ ${ }^{3}$ Centro de Investigación, Experimentación y Servicios del Champiñón, Quintanar del Rey, Spain \\ "Corresponding author: esdias@ufla.br \\ Received in May 22, 2021 and approved in July 30, 2021
}

\begin{abstract}
The cultivation of button mushroom has reached a high technological level in developed countries and is associated with high productivity indices. This technological level involves not only compost production and crop management but also the casing layer. Peat has been established as one of the most appropriate casing materials for the cultivation of button mushroom due to its excellent properties. However, good-quality peat is not available in all countries, and peat is not renewable, which reinforces the need for alternative materials. Therefore, studies on the casing layer should include its response to the induction of fruiting since this stage is where the main changes that lead to the formation of primordia occur. This review addresses the different aspects of fruiting induction of Agaricus mushrooms and the influence of the characteristics of the casing layer on mushroom production.
\end{abstract}

Index terms: Royal sun mushroom; button mushroom; fruiting induction; peat.

\begin{abstract}
RESUMO
O cultivo do cogumelo Agaricus bisporus atingiu um elevado patamar tecnológico nos países desenvolvidos, com índices de produtividade dificilmente alcançados nos países em desenvolvimento. Essa tecnologia envolve não apenas a estrutura de produção de composto e de cultivo do cogumelo, mas também a camada de cobertura. A turfa de musgo tornou-se o material preferido nos cultivos comerciais, graças às suas características desejáveis e uniformes como camada de cobertura. O problema é que a turfa de boa qualidade não é um material disponível em todos os países, gerando a necessidade de importá-la, elevando o seu custo. Além do problema da disponibilidade, a turfa não é um material renovável, o que reforça a necessidade de se buscar materiais alternativos como camada de cobertura. Diante disso, os estudos sobre camada de cobertura devem incluir a sua resposta à indução da frutificação, uma vez que é nela onde ocorrem as principais alterações que levam ao início da formação dos primórdios e desenvolvimento dos cogumelos. Esta revisão aborda os diferentes aspectos da indução da frutificação dos cogumelos Agaricus e a influência das características da camada de cobertura sobre a produção dos cogumelos.
\end{abstract}

Termos para indexação: Agaricus brasiliensis; Agaricus subrufescens; indução da frutificação; turfa.

\section{INTRODUCTION}

Among the stages of mushroom cultivation, the addition of the casing layer is essential to achieve high productivity (Pardo-Giménez et al., 2020a). The casing layer is the material used to cover the mushroom compost after complete colonization to induce the transition from vegetative to reproductive growth (Pardo-Giménez; Pardo; Zied; 2017; Grimm; Wösten, 2018). However, it should be noted that this step is not mandatory for all mushroom species, being essential for
Agaricus mushrooms and optional for Pleurotus spp. and Coprinus comatus (Figure 1). The induction of fruiting is genetically controlled but also strongly influenced by environmental factors (Sakamoto, 2018). Due to the large differences between the physicochemical properties of the casing layer and the compost, covering the compost with such a different material triggers a transition from vegetative fungal growth to the reproductive process. The casing layer therefore promotes an ecological change that is decisive in this transition and is as important as the 
quality of the compost and the management of cultivation conditions (Pardo-Giménez; Pardo; Zied, 2017). Thus, the induction of fruiting depends not only on the genetic capacity of the mycelium but also on physical, chemical and microbiological factors (Couvy, 1972; Ekman, 2017; Pardo-Giménez; De Juan; Pardo, 2002a, 2002b). In this context, the casing layer is one of the most important aspects of mushroom production influenced by these factors, in addition to the important parameters of temperature and relative humidity.

Peat is the most widely used casing material for the cultivation of Agaricus mushrooms, mainly due to its water retention capacity and porosity. However, good-quality peat, in addition to being subject to legal restrictions, is not available in all countries (Dias, 2010), and peat is not a renewable material. Therefore, the search for alternative materials has become very important. However, these materials must have appropriate microbiological and physicochemical characteristics for both good colonization and an adequate response to fruiting induction. Some of these factors will be addressed below, as well as the types of materials that can be used to replace peat.

\section{PHYSICAL AND CHEMICAL FACTORS OF THE CASING LAYER}

Physical and chemical factors, such as particle size, electrical conductivity and $\mathrm{pH}$, are considered determinants of the quality of the material used as a casing layer. Particle size has a direct effect on the compaction capacity of the casing layer and, consequently, on its water retention and aeration capacity (Colauto et al., 2010). If the casing layer has high electrical conductivity, mushroom fruiting is inhibited or drastically reduced (Pardo-Giménez; De Juan; Pardo, 2002a). Regarding $\mathrm{pH}$, although fungi can grow in a slightly acidic environment, the casing layer should have an alkaline $\mathrm{pH}$ of up to $\mathrm{pH}$ 8.0. The use of neutral or alkaline $\mathrm{pH}$ in the casing layer is important not only for the physiology of the fungus but also to help control the presence of competitors such as Trichoderma, which grow better at acidic pH (Pardo-Giménez; De Juan; Pardo, 2002a). Due to all these factors, materials are rarely used in pure form, being combined instead with other materials or corrective materials to achieve desirable properties in the casing layer, especially in terms of $\mathrm{pH}$ and porosity (Colauto et al., 2011). These materials will be discussed later.
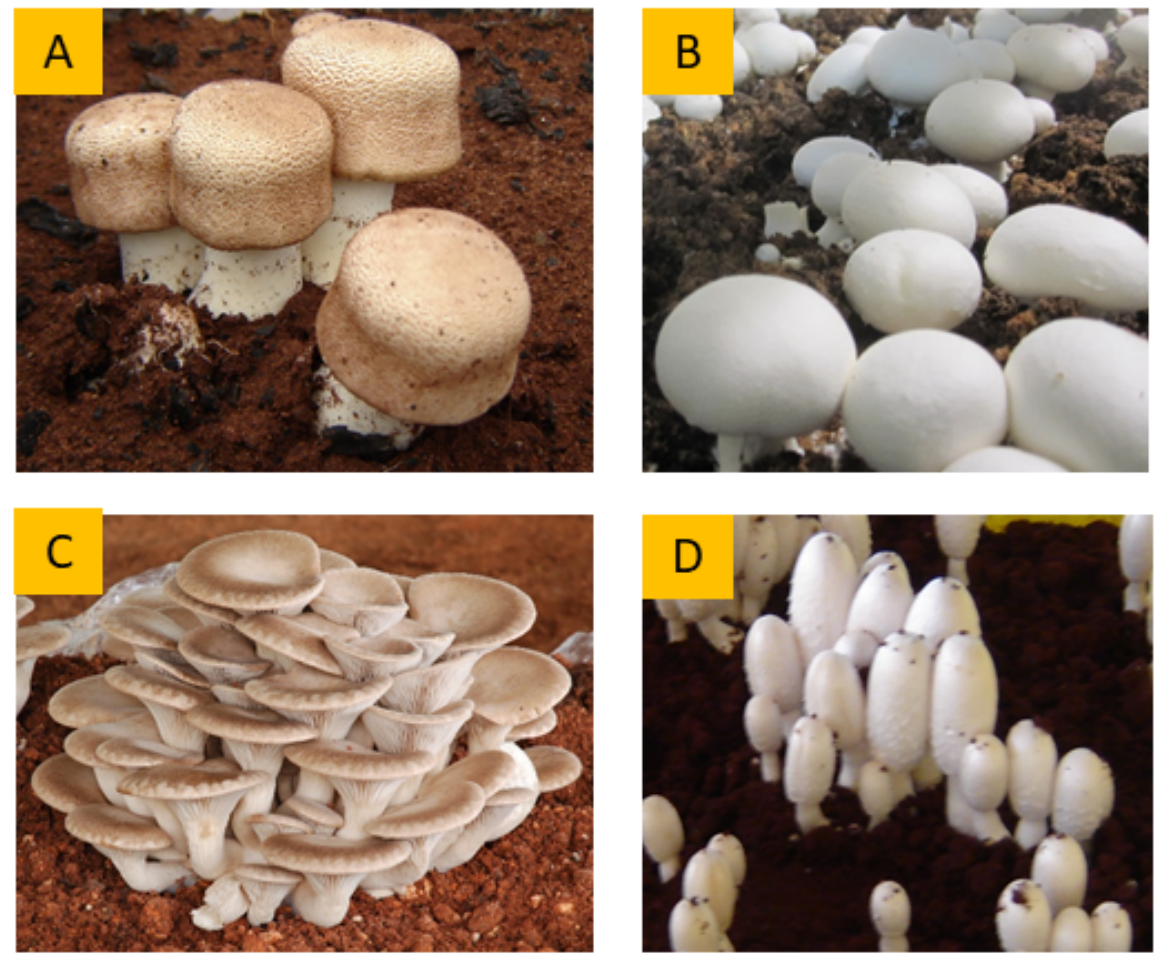

Figure 1: Mushroom cultivation using a casing layer. A: Agaricus subrufescens; B: Agaricus bisporus; C: Pleurotus eryngii; D: Coprinus comatus. 
After complete colonization of the casing layer, fruiting induction management should begin. In general, fruiting induction depends on three parameters: temperature, ventilation and relative humidity. Of course, the interactions of these factors with the casing layer determine whether effective fruiting occurs. For this reason, none of these three factors can be neglected in studies on the casing layer. Thus, the relative humidity of the air and, to a large extent, ventilation should not vary substantially from one species to another in commercial crops, except in some special cases. Temperature is therefore the factor that should undergo the greatest variation, especially for mushrooms that depend on cold conditions for fruiting.

There is no exact temperature for the induction of Agaricus bisporus fruiting; however, values between 15 and $17^{\circ} \mathrm{C}$ are usually used. According to Couvy (1972), the ideal temperature should be 7 to $9{ }^{\circ} \mathrm{C}$ below the temperature considered optimal for substrate colonization $\left(22-25^{\circ} \mathrm{C}\right)$. This temperature difference is due to ecological issues. A. bisporus is a species originating from a temperate climate in which the seasons are well defined. In nature, this seasonal definition causes the fungus to multiply vegetatively during the hot season and start to fruit in autumn (Kauserud et al., 2008; Dias; Brito, 2017). Therefore, an ambient temperature of $22-28{ }^{\circ} \mathrm{C}$ is suitable for the colonization of the substrate and the casing layer, but it is not suitable for the induction of fruiting. According to Flegg (1989), fruiting can occur without reducing the temperature; however, the resulting process would be suboptimal. After the induction of fruiting, the temperature can be returned to $25^{\circ} \mathrm{C}$, which can speed mushroom development; however, the maintenance of a low temperature also helps in the control of pathogens and contaminants (Figueirêdo; Dias, 2014).

Fruiting usually also requires high relative humidity because basidiocarps do not have defense mechanisms against dryness. When substrate colonization occurs inside bags, there is no need to maintain such a high relative humidity. Humidity restrictions change when colonization is performed in mushroom beds, in which the substrate is exposed to the environment, or when colonization occurs in perforated bags. In these cases, it is essential to maintain high relative humidity. According to Carrasco et al. (2021), the following relative humidity standards should be followed for the cultivation of A. bisporus in a bed system: a) $>95 \%$ until fruiting, b) $90-95 \%$ during fruiting and c) $80-85 \%$ during mushroom development.

Regarding aeration, it is necessary to reduce the concentration of $\mathrm{CO}_{2}$ in the air, since $\mathrm{CO}_{2}$ is extremely harmful to the development of mushrooms, although the fungi are quite tolerant to $\mathrm{CO}_{2}$ during the colonization phase. For fruiting induction, the concentration of $\mathrm{CO}_{2}$ in the air must be held at 800-1000 ppm (Rinker, 1993; Dhar, 2017). Clearly, the casing layer plays a very important role in this change in $\mathrm{CO}_{2}$ concentration in the air, since more porous materials will be more favorable to the process (Pardo-Giménez; De Juan; Pardo, 2002b). Therefore, it is essential that the ideal porosity and water holding capacity of the casing layer be balanced.

\section{MICROBIOLOGICAL FACTORS}

The importance of microbial interactions for the fruiting of mushrooms has been documented for many years. For mycorrhizal mushrooms, in addition to microbial interactions with plant roots being important, the microbial community present in the fungal mantle plays a vital role in the fruiting process (Dias; Brito, 2017). For cultivated mushrooms, interactions with other microorganisms also occur, where bacteria present in the casing layer stimulate fruiting. Several species may play this role (McGee, 2018; Murmu; Maurya; John, 2020); in particular, studies have demonstrated the participation of Pseudomonas putida (Hayes et al., 1969; Samson et al., 1987; Masaphy et al., 1987; Colauto et al., 2016; Mohammad; Alkurtany; Hassan, 2020). However, subsequent studies have shown that a mixture of Pseudomonas species or other bacterial groups is actually more effective than a single species in stimulating fruiting. According to these studies, these bacteria act in the degradation of volatile compounds that inhibit primordial formation (Noble et al., 2009).

\section{FUNCTIONS OF THE CASING LAYER}

The casing layer, as previously mentioned, plays an ecological role, simulating the conditions under which mushrooms develop in nature. However, there are several aspects of the casing layer that should be considered when establishing an appropriate environment for mushroom fruiting. Thus, the casing layer fulfills several functions: it serves as a physical support for the mushrooms, keeps the environment moist, prevents desiccation of the compost, promotes the growth of beneficial bacteria, complements the water supply for the mushrooms, allows the exchange of gases between the substrate and the environment, and provides a low-salinity environment (Pardo-Giménez; Pardo; Zied, 2017; Navarro et al., 2020).

Given the many functional aspects, it is clear that there is a complex interaction network among physical, chemical and biological variables, making it 
difficult to define the ideal requirements for a casing layer. Nevertheless, some conditions necessary for an adequate casing layer can be described (Pardo Giménez; Pardo; Zied, 2017). The casing layer must be strong and deep enough to support the growth of the mushrooms, in addition to presenting a high water absorption capacity. Additionally, the casing layer must be able to withstand frequent irrigation without losing its structure and be able to maintain good permeability to water and gases $\left(\mathrm{O}_{2}\right.$ and $\mathrm{CO}_{2}$ ). As previously mentioned, the casing layer also needs to have a low salt concentration, low nutritional value and neutral or slightly alkaline $\mathrm{pH}$. Thus, the casing layer must contain calcium carbonate and have a high cation exchange capacity. Some authors have cited magnesium as a negative factor in the casing layer; however, the relevance of magnesium is still a controversial topic (Pardo-Giménez et al., 2002b). Finally, the casing layer must be free of parasites and competitors; accordingly, pasteurization or chemical treatment of the material before use is recommended. Nevertheless, after years of studies, it was concluded that good-quality peat does not need any treatment (Rinker, 1993). In this specific case, pasteurized peat carries fewer benefits than unpasteurized peat because of its bacterial population, which plays an important role in stimulating fruiting, as discussed above. However, it is important to note that for other materials used as a casing layer, pasteurization or chemical treatment are very important practices to avoid losses in production due to pests and diseases that may be present in the material.

\section{MATERIALS USED AS CASING LAYERS}

There is a great diversity of materials of mineral, plant and even industrial or synthetic origin that can be used as a casing layer. Among these materials, peat moss stands out as the most widely used material worldwide for the cultivation of $A$. bisporus. It is generally accepted that peat moss is one of the best casing materials available today, and as a result, it is used as a reference in studies evaluating other materials. In addition to its water retention capacity, peat moss contains sufficient air spaces to allow the diffusion of oxygen, carbon dioxide and other volatile gases (Pardo-Giménez; Pardo; Zied, 2017).

\section{Mineral soil and peat-based materials}

Until the middle of the last century, sterile soil or subsoil was the standard material used as a casing layer (Chang; Miles, 2004). Since then, peat has occupied this space, not only because of its ideal characteristics but also because of the ease of acquisition of this material in countries with a temperate climate. However, there is growing concern regarding the environmental impact of the commercial exploitation of peatlands, especially in temperate and boreal regions (Joosten; Clarke, 2002; Heck et al., 2021). Given this concern, the possibility of using alternatives to peat has been explored. Naturally, the first option would be to revert to the use of soil or subsoil. In European countries, such as Spain, soil was used as the base material of the casing until a few years ago, while peat was used as a structural corrective and for its water retention capacity (Pardo-Giménez; Pardo; Zied, 2017). There is a great diversity of soils, but not all of them are viable alternatives as casing layers. Soils with a higher water retention capacity also have lower porosity and vice versa. Therefore, different types of materials have been studied as corrective materials for soil structure amendment, such as peat, sand, coconut fiber and vermiculite. Other studies, however, have addressed the use of a peat-based casing layer, which can be supplemented with alternative materials. Some of these studies will be discussed below, considering the two most relevant Agaricus species: A. bisporus and A. subrufescens.

\section{Casing layer alternatives for $\boldsymbol{A}$. bisporus cultivation}

Pardo-Giménez, Zied and Pardo-González (2012) evaluated the addition of Sphagnum peat and black peat to mineral soil at a ratio of $4: 1(\mathrm{v} / \mathrm{v})$ as a casing layer for three A. bisporus strains. The authors observed an increase in the biological efficiency (BE) of mushroom production for only one of the strains evaluated, which was also the most productive among the three. The results reported by the authors show that the response to the casing layer also depends on the genetic response of the strain used. In another study, Pardo et al. (2010) reported casing layer management approaches based on soil with different structural and water retention correctors. The authors observed that the interactions are complex and that it is not a simple task to determine the best combination.

Pardo-Giménez, Zied and Pardo-González (2012) also reported on casing layers based on Sphagnum peat and black peat, which were used alone, in combination or with the addition of spent lime in two ratios (peat:spent lime $=2: 1$ and $1: 1(\mathrm{v} / \mathrm{v}))$. The authors observed that the combination of Sphagnum peat + spent lime (2:1) provided a higher BE than black peat + spent lime $(2: 1)$, with a $93.6 \%$ BE. Similarly, the BE obtained with a $2: 1$ ratio of Sphagnum peat + spent lime was higher than that obtained with a 1:1 ratio of the same materials, with values of 105.0 and $96.1 \%$, respectively. 
Spent lime is a byproduct of the extraction of sugar from beet, obtained in the form of $\mathrm{CaCO}_{3}$, and is widespread in countries such as the Netherlands and, to a lesser extent, in the United Kingdom and the United States (Huerta; Spaulding; Kelly, 2001; Barry et al., 2016a). The interest in the use of spent lime is basically due to its buffering capacity and its ability to improve the casing layer structure. When used for this purpose, the spent lime must be sufficiently stable and must be applied in the right amount. According to the results reported by PardoGiménez, Zied and Pardo-González (2012), excess spent lime caused a reduction of $8.5 \%$ in mushroom production.

In another experiment, Pardo-Giménez, PardoGonzález and Zied (2011) evaluated the use of spent mushroom substrate (SMS) in combination with Sphagnum peat at ratios of 4:1, 3:2, 2:3 and 1:4 (Sphagnum peat + SMS $)(v / v)$. The highest BE $(110.1 \%)$ was obtained at a ratio of 4:1; however, no significant differences were observed between treatments, except for the ratio of 1:4, for which a BE of only $84.8 \%$ was observed. These results are very interesting because they demonstrate the real possibility of reusing SMS in mushroom cultivation itself. For this experiment, the authors used two mixtures as controls: a) mineral soil + coconut fiber $4: 1(\mathrm{v} / \mathrm{v})$ and b) Sphagnum peat + spent lime 2:1 (v/v). The BEs of the controls did not differ statistically from those of the treatments with Sphagnum peat + SMS, except for the treatment with a 1:4 ratio. This result demonstrates that the combination of SMS with Sphagnum peat resulted in a casing layer with the same quality as that of casing layers prepared with other materials. However, the authors emphasized the need for appropriate treatment of SMS before it can be used for this purpose. The SMS (spent compost + casing layer) was first subjected to thermal treatment $\left(70^{\circ} \mathrm{C} / 12 \mathrm{~h}\right)$ while still in the mushroom house. Then, the SMS was matured for 2 months to ensure biological stability (Lohr; Wang; Wolt, 1984). In addition to considering biological stability, it is important to pay attention to the high electrical conductivity of SMS, since this is an inhibitory factor for fruiting induction. Therefore, SMS can be used as long as it is added in the correct proportion, since mixing SMS with other materials, such as peat, reduces these values to acceptable levels.

The use of SMS is a viable and advantageous strategy, from both an economic and environmental point of view, as it can reduce the cost of the material used as a casing layer, allow the reuse of SMS and have a lower impact on the use of peat (Barry et al., 2016b; Ashrafi et al., 2017; Zied et al., 2020). The results for the different quantitative and qualitative production parameters considered in this experiment are presented in detail in the study by Pardo-Giménez, Pardo-González and Zied (2011).

\section{Casing layer alternatives for the cultivation of $A$. subrufescens}

The royal sun mushroom was identified by Heinemann in 1967 as A. blazei (Dias; Abe; Schwan, 2004). Subsequently, this mushroom was identified as another species and was renamed $A$. brasiliensis by Wasser et al. (2002) and A. subrufescens by Kerrigan (2005). To date, there is no consensus on the species of this mushroom, so the names mentioned above have been considered synonymous (Dias, 2010; Dias et al., 2008; Herreira et al., 2012). However, according to the findings of Kerrigan (2005) and based on DNA sequencing data, the name $A$. subrufescens will be used in this study.

The cultivation of royal sun mushroom was established in Brazil using the same cultivation principles as those used for button mushroom (Dias et al., 2004; Dias, 2010). However, despite belonging to the same genus and having a similar life cycle, these mushrooms are different species and originate from different habitats. This difference implies that the mushrooms are subject to distinct genetic and ecological factors. Accordingly, the need for technological development for sun mushroom is clear, and a series of studies have been conducted since the end of the last century. One of the major studies in this area was led by Prof. Eira and led to a book compiling the main results of his research (Eira, 2003). In addition to addressing the need to develop composting technology and the cultivation environment, Eira (2003) addressed the need to adapt the casing layer to Brazilian conditions. In Brazil, peat extraction is strongly regulated by environmental legislation, and tropical peat bogs are different from those of temperate and boreal origins, resulting in many variations in peat quality. As a result, the first option for the casing layer would be the use of soil, especially subsoil. To improve the characteristics of the casing layer, Eira (2003) evaluated the addition of charcoal and observed that the addition of $30 \%$ charcoal to the soil provided a $20 \%$ increase in productivity. As a result, the addition of charcoal has become a common practice in virtually all studies using soil as the casing layer (Zied et al., 2010; Zied et al., 2011). Subsequently, Zied et al. (2014) evaluated other materials as additives, such as peat moss, coconut fiber, and pine bark, and observed that they all had the same effect on mushroom production. Several other studies were conducted by both Eira's team and other Brazilian researchers and are described below. 
Siqueira et al. (2009) evaluated different soil types as casing layers for the cultivation of sun mushroom in two types of compost. The authors reported the use of charcoal only for Rhodic Hapludox soil, since this type of soil tends to stick to the mushrooms and cause deformities in them. Coincidentally, the mixture of Rhodic Hapludox soil + charcoal at a 4:1 ratio $(\mathrm{v} / \mathrm{v})$ resulted in the highest yield $(16.4 \%)$, while in the treatments with Xanthic Hapludox and Humic Haplaquox soils, the yields were only 7 and $4.8 \%$, respectively. These results were obtained when growing mushrooms in sugarcane bagasse-based compost and coastcross hay. The authors observed similar behavior when another compost formulation was used (sugarcane bagasse and corn straw) but with a lower yield of $11.2 \%$ for Rhodic Hapludox soil + charcoal and $0 \%$ for the Xanthic Hapludox and Humic Haplaquox soils. These results confirmed what was already known, that is, different soil types could result in very different results. In this case, depending on the type of compost used, productivity can be completely compromised, depending on the type of soil chosen as the casing layer. Zied et al. (2010) compared different soil types, from sandy soils to clayey soils, all of which were supplemented with $25 \%$ charcoal. According to the authors, there was no significant difference between treatments, which could be interpreted as a contradictory result. However, the addition of charcoal to all treatments was probably the element that standardized the quality of the casing layer among the different treatments. In this case, unfortunately, soils with and without charcoal were not compared; such a comparison would have allowed the evaluation of this effect.

Zied et al. (2009) reported the use of a single soil type, dystrophic Red Nitosol; however, acrylamide gel and soybean meal were tested as additives in the casing layer, in addition to $25 \%$ charcoal. Acrylamide gel was used as a conditioner, mainly for its water retention capacity, while soybean meal was used as a source of fatty acids. The authors observed that the highest production occurred in the treatment with polyacrylamide gel. This result was very interesting; however, there is concern regarding the use of polyacrylamide for agriculture because, although this gel is not toxic, it may contain approximately $0.05 \%$ acrylamide, which is known for toxicity (Woodrow, 2008). Currently, there are other options for agricultural hydrogels; thus, new studies could be conducted to evaluate the effectiveness of the products currently on the market. There is a need to evaluate the economic viability of polyacrylamide use, given the current technological developments with respect to the casing layer.
Colauto et al. (2010) searched for alternative materials to peat based on Red-Yellow Podzolic soil + charcoal. Two types of peat, obtained from São Paulo and Santa Catarina states, were tested; these peats were therefore different from the Sphagnum peat originating from the Northern Hemisphere. In addition to these materials, lime schist, a byproduct of limestone mining, which was selected for the experiment due to its good characteristics, was tested. At the end of the study, the authors concluded that peat from Santa Catarina and lime schist were the treatments that provided the highest $\mathrm{BE}$ and were superior to peat from São Paulo and the control (Red-Yellow Podzolic + charcoal). Until this study, Brazilian peat was not known for its quality in such applications, making this a very important study. In addition to the Santa Catarina peat, the São Paulo peat also showed higher production than the control (Red-Yellow Podzolic + charcoal). The performance achieved in the treatment with lime schist was also very relevant, as lime schist is a type of material that has never been used for this purpose. In a similar study, Colauto et al. (2011) evaluated the use of the same treatments but tested two strains of sun mushroom, verifying that there is a strong effect of strain on production. For the ABL/26 strain, lime schist and peat from Santa Catarina showed the best results, but for the ABL/29 strain, there was no difference between these treatments and the peat from São Paulo. In another study on lime schist, Colauto et al. (2010) reported that autoclaving lime schist had a negative effect on mushroom production. According to the authors, the pasteurization of lime schist led to greater mushroom production, raising the question of the possible microbiota present. However, considering that lime schist is a mineral material usually obtained from subsoil, other factors should be considered. Despite the success achieved with this material, no other studies on the use of lime schist in commercial crops were found. One of the reasons for this lack of research may be the fact that lime schist is not yet easily available on the market. Therefore, the use of lime schist may merit new research investments as lime schist becomes easier to acquire and its market price drops, mainly because it is a byproduct of limestone extraction.

Studies on casing layer microbiota are still scarce in Brazil. A pioneering study was conducted by Silva et al. (2007), in which the authors observed that treatment of the casing layer with formalin or steam did not negatively affect the production of sun mushroom compared to the control, which was soil without any treatment. In addition, the authors reported that none of the treatments were sufficient to eliminate all bacteria, with the exception of 
autoclaving, which is not a viable process for the treatment of the casing layer. In this regard, the authors highlighted concerns about the presence of pathogenic bacterial species that were isolated from the casing layer throughout the production cycle, such as Shigella flexneri, Salmonella enteritidis and Yersinia enterocolitica. Studies on the microbiological quality of mushrooms produced in this type of material can be quite relevant, especially for cases of in natura consumption of the product.

One of the major concerns related to the casing layer is $\mathrm{pH}$ correction. For peat, it is common to use a higher ratio of calcitic limestone to peat due to the high organic matter content of peat. For the most commonly used soils with a low organic matter content, less limestone should be used; however, Brazilian soils have an acidic $\mathrm{pH}$, with values below $\mathrm{pH} 5.0$ being common. Considering that the casing layer should have a $\mathrm{pH}$ close to or above neutral, $\mathrm{pH}$ correction is considered mandatory. In addition, there are concerns related to the magnesium content in the casing layer. Zied et al. (2012) observed a negative correlation between the presence of magnesium in the casing layer and the production of sun mushroom. The authors observed higher production in the treatment that received calcitic limestone in the casing layer than in the treatment with dolomitic limestone, although the differences were not significant. On the other hand, Martos et al. (2017) evaluated dolomitic limestone concentrations in the casing layer, observing a proportional increase in productivity as a function of the increase in limestone concentration. According to the authors, the productivity ranged from $11.4 \%$ (with $0 \%$ limestone) to $16.8 \%$ (with $40 \%$ dolomitic limestone). In fact, no significant difference was observed between $30 \%$ and $40 \%$ dolomitic limestone. These results are strong evidence that magnesium should not be a problem for sun mushroom cultivation because dolomitic limestone is much richer in magnesium than calcitic limestone.

One of the major difficulties in evaluating different studies conducted in different locations and at different times is establishing a reference for mushroom production under optimal cultivation conditions. Dias et al. (2013) reported the cultivation of sun mushroom using the same cultivation facilities used for the cultivation of button mushroom, with all environmental conditions controlled. For this study, the authors used peat moss, soil and coconut fiber as a casing layer. Naturally, it was expected that production would be higher in the treatment with peat moss. However, surprisingly, the yield observed with peat moss was only $5.8 \%$, while in the soil treatment, the yield was $18.7 \%$. Another important factor when soil was used as a casing layer was the ruffling technique, since without ruffling, the productivity was only $9.8 \%$. The same study confirmed the possibility of reaching close to $20 \%$ productivity, which can be considered very good for this species and is much higher than what is normally achieved in Brazil. However, the study showed that there is still much to be understood, since even with the use of peat, the production was low, while the use of Canadian soil resulted in one of the highest production levels achieved thus far. In summary, not all types of peat function well, even when originating from the Northern Hemisphere, and not all soils are inferior as a casing layer. One of the most important aspects of the Canadian soil used was that it was a greisol obtained from a flooded area that became extremely hard after drying, necessitating physical breakdown. Even after mechanical treatment, the soil still had a large number of clods instead of being thin and homogeneous. Most likely, the diverse soil particle size distribution generated a casing layer with excellent water absorption and porosity qualities. Therefore, it is possible that the preliminary drying and hardening of the soil provided these desirable characteristics.

Pardo-Giménez et al. (2013) compared two commercial products used as a casing layer in the cultivation of button mushroom. The material of Dutch origin used as a casing layer showed the best result, with higher production than that obtained with the commercial product of Spanish origin. Even so, the results were similar to those obtained in Brazil using mineral soil. The productivity for the Dutch casing layer was $9.7 \%$, followed by that for the Spanish product, with a value of $6.5 \%$; for the mineral soils, even when supplemented with black peat, brown peat and coconut fiber, the productivity was less than $2 \%$. The study showed that even though the commercial products were superior to mineral soils, the production results were much lower than those obtained with Canadian gleysol (Dias et al., 2013). However, in a later study, Pardo-Gimenez et al. (2020a) used the same Dutch commercial product and obtained $55.4 \%$ BE under the best conditions using a compost density of $70 \mathrm{~kg} / \mathrm{m}^{2}$. Even under other conditions, including a lower compost density, the authors reported a BE above $50 \%$ in most cases. Similarly, Pardo-Gimenez et al. (2020b) used the same material in an evaluation of different types of compost supplements, obtaining more than $50 \% \mathrm{BE}$ for all treatments. These results make it very clear that all factors are equally important for successful mushroom cultivation. An excellent casing layer can be nullified 
by low-quality compost and vice versa. In contrast, an excellent compost can improve productivity under a good casing layer and optimal environmental conditions. Unfortunately, it is not always possible to control all variables since some are beyond the control of the compost producer or the mushroom grower. Therefore, searching for materials with the smallest possible sources of variation will always be essential to ensure uniform and productive cultivation cycles.

Martos et al. (2017) tested different combinations of casing layers based on mineral soil, sand, coconut fiber and a commercial substrate for the production of vegetable seedlings. All these materials were used alone and in combination with others, but the best results were obtained with the combinations of $50 \%$ coconut fiber + $50 \%$ washed sand $(9.3 \%$ yield $)$ and $50 \%$ substrate $+50 \%$ washed sand (19.2\% yield). Among all the materials used alone, the best was coconut fiber, with a $6 \%$ yield. All the other materials had a yield lower than $4 \%$. Even when the mineral soil was combined with coconut fiber or the substrate, the yield was less than $4 \%$. Nevertheless, it should be noted that in the same study, when the authors evaluated the effect of different concentrations of dolomitic limestone, the same soil provided an $11.4 \%$ yield, while with the addition of $30 \%$ dolomitic limestone, the yield jumped to $16.7 \%$. These results have some very important implications. First, the results were highly variable due to small differences from one experiment to another, which were due to differences in the batches of raw material used in the preparation of the substrate, in addition to other uncontrolled variables. The second, very important finding is the positive effect of using a concentration of dolomitic limestone well above the need indicated for simple $\mathrm{pH}$ correction. Finally, the study revealed the possibility of using other organic substrates in addition to peat, which can produce excellent results if combined with highly granular washed sand.

Productivity is not always a reliable measure since the moisture content of compost can hinder comparisons between different treatments or different studies. Therefore, BE may be a better metric because it takes into account the mass of fresh mushrooms harvested in relation to the dry mass of the compost. In the experiment reported by Martos et al. (2017), evaluating different dolomitic limestone concentrations in the casing layer, the best result was a $16.8 \%$ yield, which corresponded to $56.1 \% \mathrm{BE}$. On the other hand, in the experiment using combinations of materials as the casing layer, the best result was a $19.2 \%$ yield; however, the $\mathrm{BE}$ in this case was lower, $48.4 \%$. These results show that the composts used in each experiment had different moisture levels. This finding demonstrates why productivity is not the best indicator for comparisons between different studies and even between different experiments. Nevertheless, productivity can be used to compare results within the same experiment and is also one of the best indicators for mushroom growers. On the other hand, not all studies present the results in terms of BE, presenting them instead in terms of yield per $\mathrm{m}^{2}$, productivity, etc.

Finally, in addition to the quality of the casing layer itself being important, some management factors can bring additional benefits. Ruffling, for example, is a technique already incorporated into the cultivation of sun mushroom, as previously discussed (Dias et al., 2013) and often reported in other studies (Pardo-Gimenez et al., $2020 \mathrm{a} ; 2020 \mathrm{~b})$. Another factor that has been the subject of controversy is the need for temperature reduction, as with button mushroom. Some authors assume that the fruiting of sun mushroom can also be induced by a decrease in temperature from $28{ }^{\circ} \mathrm{C}$ to $20{ }^{\circ} \mathrm{C}$, (Zied; Minhoni, 2009; Pardo-Giménez et al., 2020b). Martos et al. (2017) evaluated the effect of a more drastic reduction to $16^{\circ} \mathrm{C}$ for different time periods (4, 6 and 8 days); however, the authors did not observe significant differences between treatments. Other studies, however, suggested that a natural oscillation in temperature could be an important factor for inducing mushroom fruiting (Eira, 2003). In this case, if cultivation is performed in a controlled environment, it could be more effective to simulate the natural oscillation of temperature between day and night cycles. Temperature oscillations may be one of the most important factors yet to be studied in detail with respect to the cultivation of the royal sun mushroom.

\section{CONCLUSIONS}

A certain technological level has been achieved for the cultivation of button mushroom in countries where variations in compost and casing layer quality are reduced to minimum levels in facilities that allow rigorous control of cultivation conditions. However, this technological level is still difficult to achieve in other countries due to the difficulty of obtaining casing layers of the same quality at affordable costs. Studies conducted with royal sun mushroom point to new possibilities of using alternative materials as a casing layer, allowing relatively high production levels to be achieved. However, the commercial production of this mushroom is still hindered by a very long cultivation cycle. 


\section{ACKNOWLEDGMENTS}

The FAPEMIG (Fundação de Amparo à Pesquisa do Estado de Minas Gerais), FAPESP (Fundação de Amparo à Pesquisa do Estado de São Paulo in Brazil), CAPES (Coordenação de Aperfeiçoamento de Pessoal de Nível Superior), CNPq (Conselho Nacional de Desenvolvimento Científico e Tecnológico) and Patronato de Desarrollo Provincial (Diputación Provincial de Cuenca, Spain) are acknowledged for financial support. We would like to thank AJE for English language translation.

\section{REFERENCES}

ASHRAFI, R. et al. Reuse of spent mushroom substrate as casing material for the production of milky white mushroom. Journal of Bangladesh Agricultural University, 15(2):239$247,2017$.

BARRY, J. et al. Influence of rate and grading of sugar beet lime (SBL) waste on the properties and yield potential of a peat-based mushroom casing. Acta Horticulturae, 1112:307-314, 2016a.

BARRY, J. et al. Influence of irrigation management on the quantity and quality of Agaricus bisporus produced on spent mushroom substrate (SMS) based casings. Acta Horticulturae, 1112:299-305, 2016b.

CARRASCO, J. et al. Commercial cultivation techniques of mushrooms. In: SRIDHAR, K. R.; DESHMUKH, S. K. (eds.). Advances in Macrofungi: Industrial avenues and prospects. CRC Press: Boca Ratón, 2021. p.11-40.

CHANG, S.T.; MILES, P. G. Mushrooms: Cultivation, nutritional value, medicinal effect, and environmental impact. Boca Ratón: CRC Press, 2004. 451 p.

COLAUTO, N. B. et al. Thermal treatments on lime schist casing layer for Agaricus brasiliensis cultivation. Ciência Rural, 40(7):1660-1663, 2010.

COLAUTO, N. B. et al. Production flush of Agaricus blazei on Brazilian casing layers. Brazilian Journal of Microbiology, 42(2):616-23, 2011.

COLAUTO, N. B. et al. Pseudomonas putida stimulates primordia on Agaricus bitorquis. Current Microbiology, 72:482-488, 2016.

COUVY, J. Les facteurs de la fructification de l'Agaricus bisporus (champignon de couche). Bulletin de la Fédération Nationale des Cultivateurs de Champignons, 14:585$604,1972$.
DHAR, B. L. Mushroom farm design and technology of cultivation. In: ZIED, D. C.; PARDO GIMÉNEZ, A. (eds.). Edible and medicinal mushrooms: Technology and applications. First Edition. John Wiley \& Sons: Chichester, p.271-308, 2017.

DIAS, E. S. Mushroom cultivation in Brazil: Challenges and potential for growth. Ciência e Agrotecnologia, 34(4):795803, 2010.

DIAS, E. S.; BRITO, M. R. Mushrooms: Biology and life cycle. In: ZIED, D. C.; PARDO GIMÉNEZ, A. (eds.). Edible and Medicinal Mushrooms: Technology and applications. First Edition. John Wiley \& Sons: Chichester, p.15-32, 2017.

DIAS, E. S.; ABE, C.; SCHWAN, R. F. Truths and myths about the mushroom Agaricus blazei. Scientia Agricola, 61(5):545549, 2004.

DIAS, E. S. et al. Cytological studies of Agaricus brasiliensis. World Journal of Microbiology and Biotechnology, 24:2473-2479, 2008.

DIAS, E. S. et al. Physiologic response of Agaricus subrufescens using different casing materials and practices applied in the cultivation of Agaricus bisporus. Fungal Biology, 117(78):569-575, 2013.

EIRA, A. F. Cultivo do cogumelo medicinal Agaricus blazei (Murril) ss. Heinemann ou Agaricus brasiliensis (Wasser et al.). Viçosa: Aprenda Fácil, 2003. 390p

EKMAN, J. Pre-and postharvest management of mushrooms. Horticulture Innovation Australia Limited: Sydney, 2017. 59p.

FLEGG, P. B. Crop production. Mushroom Journal, 197:157$163,1989$.

FIGUEIRÊDO, V. R.; DIAS, E. S. Buton mushroom cultivation in function of temperature. Ciência Rural, 44(2):241-246, 2014.

GRIMM, D.; WÖSTEN, H. A. B. Mushroom cultivation in the circular economy. Applied Microbiology and Biotechnology, 102:7795-7803, 2018.

HAYES, W. A.; RANDLE, P. E.; LAST, F. T. The nature of the microbial stimulus affecting sporophore formation in Agaricus bisporus (Lange) sing. Annals of Applied Biology, 64(1):177-187, 1969.

HECK, M. A. et al. Axenic in vitro cultivation of 19 peat moss (Sphagnum L.) species as a resource for basic biology, biotechnology, and paludiculture. New Phytologist, 229(2):861-876, 2021. 
HERREIRA, K. M. S. et al. Electron microscopy studies of basidiosporogenesis in Agaricus brasiliensis. Mycologia, 104(6):1272-1280, 2012.

HUERTA, F.; SPAULDING, T.; KELLY, C. Investigations on casing soils with a high mineral content. Mushroom News, 49(10):4-9, 2001.

JOOSTEN, H.; CLARKE, D. Wise use of mires and peatlands: background and principles including a framework for decisionmaking. Saarijärvi, Finland: International Mire Conservation Group and International Peat Society, 2002. 304p.

KAUSERUD, $\mathrm{H}$. et al. Mushroom fruiting and climate change. Proceedings of the National Academy of Sciences of the United States of America, 105(10):3811-3814, 2008.

KERRIGAN, R. W. Agaricus subrufescens, a cultivated edible and medicinal mushroom, and its synonyms. Mycologia, 97(1):12-24, 2005.

LOHR, V. I.; WANG, S. H.; WOLT, J. D. Physical and chemical characteristics of fresh and aged spent mushroom compost. HortScience, 19(5):681-683, 1984.

MCGEE, C. F. Microbial ecology of the Agaricus bisporus mushroom cropping process. Applied Microbiology and Biotechnology, 102:1075-1083, 2018.

MARTOS, E. T. et al. Casing layer and effect of primordia induction in the production of Agaricus subrufescens mushroom. Agriculture and Natural Resources, 51(4):231-234, 2017.

MASAPHY, S. et al. Scanning electron microscope studies of interactions between Agaricus bisporus (Lange) Sing hyphae and bacteria in casing soil. Applied and Environmental Microbiology, 53(5):1132-1137, 1987.

MOHAMMAD, A. O.; ALKURTANY, A. E. S.; HASSAN, A. A. Evaluation of API 20E system in fluorescent pseudomonas identification from button mushroom Agaricus bisporus cultivation casing soil. Notulae Scientia Biologicae, 12(2):258-263, 2020.

MURMU, R.; MAURYA, A. K.; JOHN, V. Mycoflora of certain casing materials used in the production of white button mushroom (Agaricus bisporus (Lange) Imbach). International Journal of Chemical Studies, 8(2):2863-2868, 2020.

NAVARRO, M. J. et al. Agronomical valuation of a drip irrigation system in a commercial mushroom farm. Scientia Horticulturae, 265(30):109234, 2020.

NOBLE, R. et al. Volatile C8 compounds and pseudomonads influence primordium formation of Agaricus bisporus. Mycologia, 101(5):583-591, 2009.
PARDO, A. et al. Modeling the effect of the physical and chemical characteristics of the materials used as casing layers on the production parameters of Agaricus bisporus. Archives of Microbiology, 192:1023-1030, 2010.

PARDO-GIMÉNEZ, A.; DE JUAN, J. A.; PARDO, J. E. Factores que influyen en la iniciación de la fructificación del champiñón cultivado. I. Factores físicos y ambientales. Factores químicos y nutritivos. ITEA Producción Vegetal, 98(1):33-43, 2002a.

PARDO-GIMÉNEZ, A.; DE JUAN, J. A.; PARDO, J. E. Factores que influyen en la iniciación de la fructificación del champiñón cultivado. II. Factores microbiológicos. ITEA Producción Vegetal, 98(2):87-94, 2002b.

PARDO-GIMÉNEZ, A.; ZIED, D. C.; PARDO-GONZÁLEZ, J. E. The use of peat as casing material in mushroom cultivation. In: DRAGUHN, C.; CIARIMBOLI, N. (eds.). Peat: Formation, uses and biological effects. New York: Nova Science Publishers, p.81-100, 2012.

PARDO-GIMÉNEZ, A.; PARDO-GONZÁLEZ, J. E.; ZIED, D. C. Evaluation of harvested mushrooms and viability of Agaricus bisporus growth using casing materials made from spent mushroom substrate. International Journal of Food Science and Technology, 46(4):787-792, 2011.

PARDO-GIMÉNEZ, A. et al. Análisis proximal de carpóforos de Agaricus subrufescens peck producidos sobre diferentes capas de cobertura. ITEA Producción Vegetal, 109(3):290302, 2013.

PARDO-GIMÉNEZ, A.; PARDO, J. E.; ZIED, D. C. Casing materials ant techniques in Agaricus bisporus cultivation. In: ZIED, D. C.; PARDO GIMÉNEZ, A. (eds.). Edible and medicinal mushrooms: Technology and applications. First Edition. John Wiley \& Sons: Chichester, p.149-174, 2017.

PARDO-GIMÉNEZ, A. et al. Influence of substrate density and cropping conditions on the cultivation of sun mushroom. Spanish Journal of Agricultural Research, 18(2):e0902, 2020a.

PARDO-GIMÉNEZ, A. et al. Optimization of cultivation techniques improves the agronomic behavior of Agaricus subrufescens. Scientific Reports, 10:8154, 2020b.

RINKER, D. L. Commercial mushroom production. Ontario: Horticultural Research Institute of Ontario, Publication 350, 1993. $41 \mathrm{p}$.

SAKAMOTO, Y. Influences of environmental factors on fruiting body induction, development and maturation in mushroom-forming fungi. Fungal Biology Reviews, 32(4):236-248, 2018. 
SAMSON, R. et al. Variability of fluorescent pseudomonads populations in composts and casing soils used for mushroom cultures. In: WUEST, P. J.; ROYSE, D. J.; BEELMAN, R. B. (Eds.). Developments in crop science 10: Cultivating edible fungi. Elsevier Science Publishing: New York, p.19-25, 1987.

SILVA, V. A. Isolation and identification of bacteria present in the casing layer utilized to the cultivation of the mushroom Agaricus blazei Murril. Ciência e Agrotecnologia, 31(5):1364-1373, 2007.

SIQUEIRA, F. G. et al. Cultivation of Agaricus blazei ss. Heinemann using different soils as source of casing materials. Scientia Agricola, 66(6):827-830, 2009.

ZIED, D. C.; MINHONI, M. T. A. Influence of the environment of production in yield of mushroom Agaricus blazei ss. Heinemann ( $A$. brasiliensis). Energia na Agricultura, 24(1):17-34, 2009.

ZIED, D. C. et al. Produção de Agaricus blazei ss. Heinemann (A. brasiliensis) em função de diferentes camadas de cobertura e substratos de cultivo. Interciencia, 34(6):437442, 2009.

ZIED, D. C. et al. A study of compost added to casing technique in Agaricus bisporus cultivation from Phase III bulk compost. HortScience, 45(11):1649-1653, 2010.
ZIED, D. C. et al. Medicinal mushroom growth as affected by non-axenic casing soil. Pedosphere, 21(2):146-153, 2011.

ZIED, D. C. et al. Characterization, feasibility and optimization of Agaricus subrufescens growth based on chemical elements on casing layer. Saudi Journal of Biological Sciences, 19(3):343-347, 2012.

ZIED, D. C. et al. Effect of cultivation practices on the $\beta$-glucan content of Agaricus subrufescens basidiocarps. Journal of Agricultural and Food Chemistry, 62(1):4149, 2014.

ZIED, D. C. et al. Use of spent mushroom substrate in new mushroom crops to promote the transition towards a circular economy. Agronomy, 10(9):1239, 2020.

WASSER, S. P. et al. Is a widely cultivated culinary-medicinal royal sun agaricus (the Himematsutake Mushroom) indeed Agaricus blazei Murrill? International Journal of Medicinal Mushrooms, 4:267-290, 2002.

WOODROW, J. E.; SEIBER, J. N.; MILLER, G. C. Acrylamide release resulting from sunlight irradiation of aqueous polyacrylamide/iron mixtures. Journal of Agricultural and Food Chemistry, 56(8):2773-2779, 2008. 